\title{
Pengaruh Dana Pihak Ketiga, Capital Adequacy Ratio (CAR), dan Non Performing Financing (NPF) Terhadap Likuiditas Perbankan Syariah Di Indonesia Tahun 2015-2019
}

\author{
Kurniawan Yogi Saputro ${ }^{1}$, Arini Wildaniyati ${ }^{2}$ \\ ${ }^{\text {I} P r o g r a m ~ S t u d i ~ A k u n t a n s i, ~ U n i v e r s i t a s ~ M e r d e k a ~ M a d i u n, ~ J l . ~ S e r a y u ~ N o ~ 79, ~ M a d i u n, ~} 63133$ \\ Email: kurniawanyogi25@gmail.com \\ ${ }^{2}$ Program Studi Akuntansi, Universitas Merdeka Madiun, Jl. Serayu No 79, Madiun, 63133 \\ Email: arini@unmer-madiun.ac.id
}

\begin{abstract}
This study aims to determine the effect of Third Party Funds on Liquidity, the effect of Capital Adequacy Ratio (CAR) on Liquidity, the effect of Non Performing Financing (NPF) on Liquidity, and the influence of Third Party Funds, Capital Adequacy Ratio (CAR), and Non Performing Financing ( NPF) against Liquidity. The sampling technique used was purposive sampling technique. The data obtained comes from secondary data in the form of banking annual financial reports for 2015-2019 which are downloaded from the official website of the bank concerned. Data analysis was performed using descriptive statistics, classical assumption test, multiple linear regression analysis, determinant coefficient test, $t$ test and $F$ test. The results of the hypothesis research indicate that the Third Party Funds variable is 0,000, the Capital Adequacy ratio (CAR) variable is 0.013, the variable NonPerforming Financing is 0.196, and simultaneously is 0.000. With these results it can be stated that only Third Party Funds, Capital Adequacy Ratio (CAR) have a positive and significant effect on Liquidity, while Non Performing Financing (NPF) has no positive and significant effect on liquidity. Simultaneously, Third Party Funds, Capital Adequacy Ratio (CAR), Non Performing Financing (NPF), have a positive and significant effect on liquidity.
\end{abstract}

Keywords—: Third Party Funds; Capital Adequacy Ratio, Non Performing Financing, and Liquidity.

\section{PENDAhULUAN}

Menurut UU Nomor 21 tahun 2008 tentang Perbankan Syariah Pasal 1 Nomor 7, Bank Syariah merupakan bank yang menjalankan kegiatan usahanya berdasarkan prinsip syariah dan menurut jenisnya terdiri atas Bank Umum Syariah dan Bank Pembiayaan Rakyat Syariah.

Seperti yang dilansir dari Bank Indonesia, sistem perbankan syariah yang beroperasi didasarkan pada prinsip bagi hasil yang saling menguntungkan bagi masyarakat maupun bank. Perbankan syariah menyediakan berbagai macam produk serta layanan jasa perbankan yang beragam dengan bentuk yang lebih variatif. Dengan demikian perbankan syariah dapat menjadi alternatif perbankan yang dapat dipercaya serta dapat dinikmati oleh seluruh golongan masyarakat.

Perkembangan perbankan syariah di Indonesia dimulai sejak tahun 1990an. Saat itu berdiri Bank Muamalat Indonesia (BMI), yang merupakan bank pertama yang menjalankan operasionalnya berdasarkan prinsip syariah. Bank Muamalat Indonesia didirikan pada tanggal 1 November 1991, yang digagas oleh Majelis Ulama Indonesia (MUI), dan mulai beroperasi pada tanggal 1 Mei 1992 (Antonio, 2016). Pada awal masa operasinya, keberadaan bank syariah belum mendapatkan perhatian yang optimal dalam tatanan sektor perbankan nasional. Namun bank syariah mulai menyita perhatian masyarakat setelah Bank Muamalat Indonesia mampu bertahan menghadapi tekanan akibat krisis moneter yang melanda Indonesia pada tahun 1998 (Nuraini, 2011).

Tantangan yang dihadapi industri perbankan syariah pada tahun 2019 adalah likuiditasnya. Ketatnya likuiditas dapat dilihat dari pertumbuhan dana pihak ketiga tahun 2019 yaitu sebesar 11,93\% yang mengalami sedikit kenaikan dari tahun 2018 sebesar 11,14\%. Presentase tersebut jauh menurun dari tahun 2017 yang mencapai 19,89\%. Selain itu, pertumbuhan aset perbankan syariah terus mengalami penurunan. Pada tahun 2019 pertumbuhan aset perbankan syariah sebesar $9.93 \%$ jauh bila dibandingkan tahun 2018 sebesar 12,57\%. Hal tersebut juga diikuti dengan pertumbuhan market share yang juga masih lesu. Market share bank syariah per Juni tahun 2019 sebesar 5,95\% meskipun mengalami kenaikan dibandingkan tahun 2018 sebesar 5,70\% dengan periode yang sama, namun dengan angka tersebut tentu saja market share bank syariah masih jauh bila dibandingkan dengan bank konvensional (www.ojk.go.id). Oleh karena itu perbankan syariah khususnya di Indonesia dituntut untuk meningkatkan performa dalam bisnisnya dan mempertahankan stabilitas sistem perbankan guna menghadapi persaingan industri perbankan. Hal ini disebabkan karena kesehatan bank merupakan hal yang penting bagi bank dalam mempertahankan stabilitas sistem perbankan. Pentingnya menjaga kesehatan bank bertujuan agar nasabah tetap memberikan kepercayaan kepada bank yang bersangkutan. 
Website : http://ekomaks.unmermadiun.ac.id/index.php/ekomaks

Bank dalam menjalankan kegiatan bisnis hendaknya selalu menjaga keseimbangan antara tingkat likuiditas yang sehat, pemenuhan kebutuhan modal yang memadai serta pengelolaan biaya operasional yang baik. Suatu bank besar yang mengalami kebangkrutan dapat menyebabkan penarikan dana secara tiba-tiba kepada bank lainnya (Suhartono, Zahroh, \& Azizah, 2017).

Manajemen likuiditas memiliki fungsi yang salah satunya ialah untuk memberikan keyakinan kepada para penyimpan dana bahwa nasabah dapat menarik sewaktu-waktu dananya atau pada saat jatuh tempo dana tersebut dapat ditarik. Oleh karena itu bank wajib mempertahankan sejumlah dana likuid agar bank dapat memenuhi kewajibannya tersebut. Likuiditas merupakan salah satu alat ukur guna menilai tingkat kesehatan suatu bank yang dilihat dari laporan keuangan yang dipublikasikan. Beberapa indikator yang digunakan untuk menilai likuiditas suatu bank yakni dengan Quict Ratio, Investing Policy Ratio, Banking ratio,Assets to Loan Ratio, Investment Portofolio Ratio, Cash Ratio, dan Loan to Deposit Ratio/ Financing to Deposit Ratio (Kasmir, 2019).

Kasmir (2019) menjelaskan bahwa dalam penilaian likuiditas salah satunya dapat dinilai salah satunya dengan menggunakan ratio Loan to Deposit Ratio (LDR) atau dalam bank syariah disebut juga Financing to Deposit Ratio (FDR). Karena dalam perhitungan analisis rasio likuiditas menggunakan FDR ini dapat menunjukkan sejauh mana kemampuan bank dalam memenuhi permintaan kredit kepada nasabah, sehingga bank dapat melaksanakan kewajibannya untuk segera memnuhi permintaan deposan yang ingin menarik kembali dananya (Dendawijaya, 2009).

Dana Pihak Ketiga (DPK) menjadi salah satu faktor penunjang kinerja dalam melaksanakan kegiatan operasional lembaga keuangan. Dana Pihak Ketiga merupakan dana yang dihimpun dari masyarakat luas yang menjadi sumber dana bagi kegiatan operasional suatu bank. Disini dapat dilihat bahwa peran DPK menjadi penting dalam bank syariah. DPK mencakup Giro, deposito, tabungan (Bank, 2004).

Penelitian terdahulu yang menghubungkan dana pihak ketiga terhadap likuiditas yang dilakukan oleh Susilowati (2016), Muttaqin (2018), dan Utami \& Muslikhati (2019) menyatakan bahwa dana pihak ketiga berpengaruh positif dan signifikan terhadap likuiditas. Hal yang sama juga di dukung oleh penelitian yang dilakukan Masruroh (2018) yang juga mengatakan bahwa dana pihak ketiga berpengaruh terhadap likuiditas.

Selain Dana Pihak Ketiga, faktor yang mempengaruhi likuiditas yaitu Capital Adequacy Ratio (CAR), yaitu rasio permodalan yang digunakan untuk mengukur kemampuan suatu bank dalam mencadangkan dana untuk keperluan untuk keberlangsungan usaha dan mengcover risiko kerugian dana imbas dari kegiatan operasionalnya. Semakin tinggi nilai CAR maka semakin besar pula kemampun finansial yang dapat digunakan untuk keberlangsungan usaha dan mengantisipasi potensi kerugian imbas dari penyaluran kredit (Susilowati, 2016).

Capital Adequacy Ratio (CAR) pada penelitian Muttaqin (2018) dan Masruroh (2018) menunjukkan berpengaruh positif terhadap likuiditas. Hasil penelitiaan tersebut tidak konsisten dengan penelitian yang dilakukan Utami \& Muslikhati (2019) yang menyatakan bahwa CAR tidak berpengaruh terhadap likuiditas.

Faktor lainnya yang mempengaruhi likuiditas yaitu Non Performing Financing (NPF). Besarnya NPF sesuai dengan ketentuan Bank Indonesia yaitu maksimal 5\% dari seluruh pembiayaan yang disalurkan. NPF merupakan rasio perbandingan antara pinjaman bermasalah terhadap total pinjaman yang diberikan kepada pihak ketiga. Sehingga semakin tinggi NPF pada bank syariah maka mengindikasikan bahwa kinerja bank tersebut buruk. Dengan begitu maka NPF menjadi parameter yang dapat mempengaruhi tingkat likuiditas dan dijadikan ukuran untuk tinggi rendahnya likuiditas pada perbankan (Muttaqin, 2018).

Menurut penelitian Susilowati (2016) menunjukkan bahwa Non Performing Financing (NPF) berpengaruh terhadap likuiditas. Hal ini berbeda dengan penelitian yang dilakukan oleh Masruroh (2018) yang menyatakan NPF berpengaruh negatif terhadap likuiditas.

A. Berdasarkan uraian yang telah dijelaskan, maka penulis tertarik untuk mengadakan penelitian pada industri perbankan syari'ah dengan judul: “Pengaruh Dana Pihak Ketiga (DPK), Capital Adequacy Ratio (CAR), dan Non Performing Financing (NPF) Terhadap Likuiditas Perbankan Syariah Di Indoneisa Tahun 2015-2019”

\section{METODE PENELITIAN}

Metode penelitian yang digunakan dalam penelitian ini adalah metode kuantitaif, karena penelitian ini disajikan dengan angka-angka. Populasi pada penelitianini adalah Perbankan Syariah Di Indonesia selama 5 tahun. Teknik sampling pengambilan sampel yang digunakan adalah Teknik Purposive Sampling karena sampel yang dipilih berdasarkan kriteria tertentu. Sehingga sampel pada penelitian ini berjumlah 30, .Sumber data yang digunakan berasal dari data sekunder. Data sekunder ini berupa dokumen Laporan Keuangan Tahunan Bank Syariah yang diunduh dari situs resmi perbankan syariah yang dijadikan sampel.

\section{A. Likuiditas (Y)}

Variabel dependen dalam penelitian ini adalah Likuiditas. Menurut Kasmir (2014), "Likuiditas merupakan kemampuan bank untuk memenuhi kewajiban hutang-hutangnya, dapat membayar kembali semua deposannya serta dapat memenuhi permintaan kredit yang diajukan oleh para debitur tanpa terjadi penangguhan”.

\section{B. Dana Pihak Ketiga (X1)}

Menurut peraturan Bank Indonesia 17/11/PBI/2015 Dana Pihak Ketiga Bank yang selanjutnya disingkat DPK adalah kewajiban Bank kepada penduduk dan bukan penduduk dalam rupiah dan valuta asing. Dana pihak ketiga merupakan sumber 
Website : http://ekomaks.unmermadiun.ac.id/index.php/ekomaks

utama pendanaan perbankan. Maka dari itu sumber dana ini dana terpenting bagi kegitan operasional suatu bank dan merupakan ukuran keberhasilan bank jika mampu membiayai operasionalnya dari sumber dana ini (Kasmir, 2014).

\section{Capital Adequacy Ratio (X2)}

Capital Adequacy Ratio adalah sebuah rasio yang memperlihatkan seberapa jauh kemampuan bank dalam menyediakan dana untuk keperluan usaha dan menampung resiko kerugian dana yang diakibatkan dari kegiatan operasional. Menurut Ikatan Bankir Indonesia (IBI) (2014), menyebutkan bahwa Capital Adequacy Ratio merupakan Rasio Kewajiban Modal Minimum (KPPM) yang harus dipenuhi bank..

\section{Non Performing Financing (X3)}

Non Perfroming Loan (NPL) atau Non Performing Financing (NPF) menurut IBI (2014), merupakan kredit bermasalah yang terdiri dari kredit yang berklasifikasi kurang lancar, diragukan, dan macet. Termin NPL digunakan untuk bank umum, sedangkan NPF untuk bank syariah. Rasio ini digunakan untuk mengukur tingkat permasalahan pembiayaan yang dihadapi oleh bank. Non Performing Financing atau risiko kredit merupakan indikator yang digunakan untuk menunjukkan kerugian akibat risiko pembiayaan.

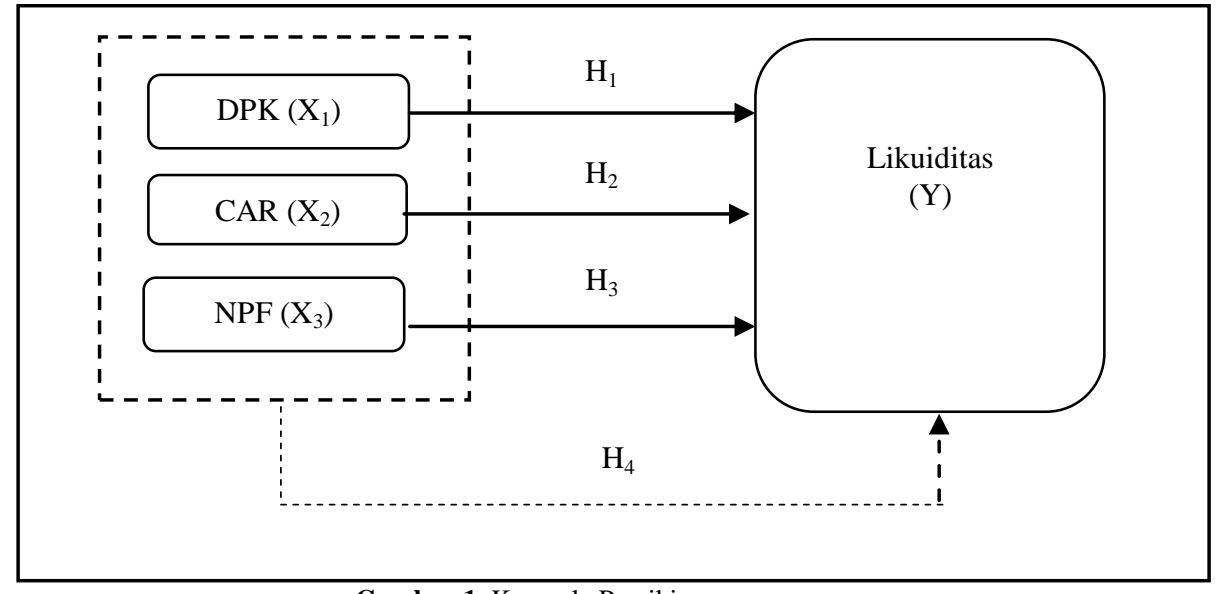

Gambar 1. KerangkaPemikiran

Hipotesis dalam penelitian ini adalah sebagai berikut:

H1 :Variabel Dana Pihak Ketiga berpengaruh signifikan terhadap Likuiditas Perbankan Syariah Di Indonesia Tahun 20152019

H2 : Variabel Capital Adequacy Ratio (CAR) berpengaruh signifikan terhadap Likuiditas Perbankan Syariah Di Indonesia Tahun 2015-2019

H3 : Variabel Non Performing Financing (NPF) berpengaruh signifikan terhadap Likuiditas Perbankan Syariah Di Indonesia Tahun 2015-2019.

H4 : Variabel DPK, CAR, dan NPF berpengaruh signifikan terhadap Likuiditas pada Perbankan Syariah Di Indonesia Di Indonesia Tahun 2015-2019

\section{III.HASIL DAN PEMBAHASAN}

\section{A. Hasil}

Teknik pengujian hipotesis pada penelitian ini menggunakan uji analisis regresi linear berganda. Pengujian regresi linear berganda ini dimaksudkan untuk menguji variabel yang berpengaruh terhadap likuiditas. Pengujian menggunakan program SPSS.

Tabel 1. Hasil Pengujian Koefisien Determinansi

Model Summary ${ }^{b}$

\begin{tabular}{|c|c|c|c|c|}
\hline Model & $\mathrm{R}$ & R Square & $\begin{array}{c}\text { Adjusted R } \\
\text { Square }\end{array}$ & $\begin{array}{l}\text { Std. Error of the } \\
\text { Estimate }\end{array}$ \\
\hline 1 &, $708^{\mathrm{a}}$ & ,501 & ,443 & 6,77605 \\
\hline
\end{tabular}

a. Predictors: (Constant),NPF, Ln_DPK, CAR

b. Dependent Variable: FDR

Sumber: Data primer diolah, 2020

Berdasarkan Tabel 1 di atas dapat dijelaskan bahwa nilai Koefisien Determinansi (Adjusted R Square) yang diperoleh adalah 0,443. Artinya bahwa variasi kelima variable bebas, yaitu DPK, CAR, dan NPF, memberikan kontribusi terhadap Likuiditas sebesar $44,3 \%$ sedangkan $55,7 \%$ lainnya dapat dijelaskan oleh variabel lain yang tidak termasuk dalam penelitian. Pengujian selanjutnya dilakukan dengan pengujian simultan atau uji F yang hasilnya dapat dilihat pada table dibawah ini. 
Website : http://ekomaks.unmermadiun.ac.id/index.php/ekomaks

Tabel 2. Hasil Uji F

ANOVA $^{\mathrm{a}}$

\begin{tabular}{|ll|r|r|r|r|r|}
\hline Model & & Sum of Squares & df & Mean Square & \multicolumn{1}{c|}{ F } & \multicolumn{1}{c|}{ Sig. } \\
\hline 1 & Regression & 1198,710 & 3 & 399,570 & 8,702 &, $000^{\mathrm{b}}$ \\
\cline { 2 - 7 } & Residual & 1193,786 & 26 & 45,915 & & \\
& Total & 2392,496 & 29 & & & \\
\hline
\end{tabular}

a. Dependent Variable: FDR

b. Predictors: (Constant), NPF, Ln_DPK, CAR

Sumber: Data primer diolah, 2020

Berdasarkan dari Tabel 2 menunjukkan bahwa nilai Sig. sebesar 0,000 <nilai $\alpha$ sebesar 0,05. Karena nilai Sig. lebih kecil dari 0,05, maka dapat disimpulkan bahwa hipotesis diterima yang artinya ada pengaruh yang positif dan signifikan antara DPK, CAR, dan NPF terhadap Likuiditas pada Perbankan Syariah Di Indonesia tahun 2015-2019. Tahapan uji selanjutnya adalah uji parsial atau uji t yang hasilnya dapat dilihat pada table dibawah ini.

Tabel 3. Hasil uji t

Coefficients $^{\mathrm{a}}$

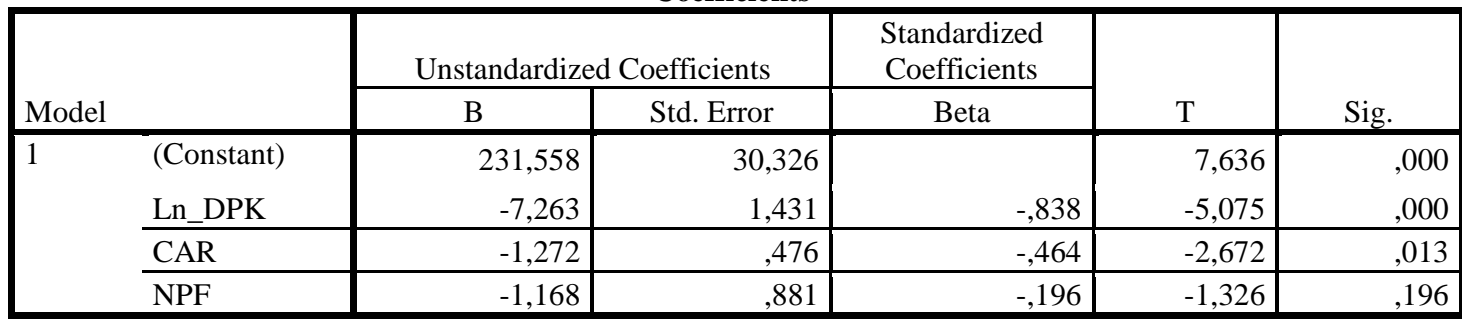

a. Dependent Variable: FDR

Sumber: Data primer diolah, 2020

Berdasarkan Tabel 3 menunjukkan bahwa 3 variabel independen yang dimasukkan dalam persamaan regresi, terdapat 2 variabel yang berpengaruh terhadap likuiditas. Nilai sig. DPK menunjukkan $0,000<0,05$ sehingga $\mathrm{H}_{1}$ diterima. Nilai sig. CAR menunjukkan 0,013 $<0,05$ sehingga $\mathrm{H}_{2}$ diterima. Sedangkan Nilai sig. NPF menunjukkan 0,196> 0,05 sehingga $\mathrm{H}_{3}$ ditolak.

\section{B. Pembahasan}

\section{Pengaruh DPK terhadap Likuiditas}

Hipotesis pertama yang diajukan dalam penelitian ini yaitu variabel Dana Pihak Ketiga (DPK) memiliki pengaruh terhadap Likuiditas (FDR). Hal ini bisa dilihat dari perolehan nilai sig. sebesar $0,000<0,05$, sehingga DPK berpengaruh positif dan signifikan terhadap likuiditas (FDR). Dengan demikian $\mathrm{H}_{1}$ dapat diterima.

DPK merupakan dana yang berasal dari masyarakat yang dihimpun dalam bentuk giro, tabungan, dan deposito. DPK digunakan untuk pembiayaan operasional bank. Hasil penelitian telah menunjukkan adanya pengaruh yang signifikan variabel DPK terhadap Likuiditas (FDR) hal ini dikarenakan semakin meningkatnya Dana Pihak Ketiga yang dihimpun bank maka semakin meningkatkan pembiayaan yang akan diberikan oleh bank. Meningkatnya pembiayaan akan mempengaruhi peningkatan likuiditas bank.

Hasil penelitian ini mendukung penelitian yang dilakukan oleh Masruroh (2018) yang menunjukan bahwa DPK dengan nilai Sig. sebesar 0,000 < 0,05 yang artinya DPK berpengaruh positif dan siginifkan terhadap Likuiditas (FDR). Senada dengan penelitian yang dilakukan Muttaqin (2018) yang menunjukkan bahwa DPK dengan nilai Sig. sebesar 0,005 < 0,05 yang artinya DPK terdapat pengaruh yang positif dan signifikan variabel DPK terhadap Likuidtas (FDR) dan Susilowati (2016) yang menunjukkan bahwa DPK dengan nilai Sig. sebesar 0,013 < 0,05 yang artinya DPK berpengaruh positif dan signifikan terhadap Likuiditas (FDR).

\section{Pengaruh CAR terhadap Likuiditas}

Hipotesis kedua yang diajukan dalam penelitian ini yaitu variabel Capital Adequacy Ratio (CAR) memiliki pengaruh yang terhadap Likuiditas (FDR). Hal ini bisa dilihat dari perolehan nilai sig. sebesar $0,013<0,05$, sehingga CAR berpengaruh positif dan signifikan terhadap likuiditas (FDR). Dengan demikian $\mathrm{H}_{2}$ dapat diterima.

CAR merupakan indikator dalam menilai kemampuan bank untuk membayar kerugian akibat dari kegiatan operasionalnya. Hasil penelitian menunjukkan adanya pengaruh yang signifikan variabel CAR terhadap Likuiditas (FDR) hal ini dikarenakan apabila bank mampu meningkatkan rasio permodalannya maka bank mampu mengatasi risiko-risiko yang timbul dalam pembiayaan dalam kegiatan operasionalnya. Kemampuan bank dalam mengatasi risko tersebut menyebabkan likuiditas bank akan terjaga dengan baik. 
Website : http://ekomaks.unmermadiun.ac.id/index.php/ekomaks

Hasil penlitian ini mendukung penelitian yang dilakukan oleh Masruroh (2018) menunjukkan bahwa CAR dengan nilai Sig. sebesar 0,005 < 0,05 yang artinya CAR berpengaruh siginifkan terhadap Likuiditas (FDR) dan Muttaqin (2018) yang menunjukkan CAR dengan nilai Sig. sebesar $0,0301<0,05$ yang artinya CAR berpengaruh positif dan signifikan dan signifikan terhadap Likuiditas (FDR). Hasil berbeda didapati oleh Susilowati (2016) yang menunjukkan bahwa CAR dengan nilai nilai Sig. sebesar 0,418 > 0,05 yang artinya CAR tidak berpengaruh terhadap likuiditas.

\section{Pengaruh NPF terhadap Likuiditas}

Hipotesis ketiga yang diajukan dalam penelitian ini yaitu variabel Non Performing Financing (NPF) tidak memiliki pengaruh terhadap Likuiditas (FDR). Hal ini bisa dilihat dari perolehan nilai sig. sebesar 0,196 > 0,05, sehingga NPF tidak berpengaruh signifikan terhadap likuiditas (FDR). Dengan demikian $\mathrm{H}_{3}$ ditolak.

NPF merupakan rasio yang menggambarkan perbandingan antara kredit bermasalah dengan kredit yang diberikan oleh bank. Semakin tinggi rasio NPF ini mengindikasikan kinerja bank yang buruk. Hasil penelitian menunjukkan tidak adanya pengaruh yang signifikan variabel NPF terhadap Likuiditas (FDR). Hal ini bisa disebabkan karena peningkatan NPF yang tergolong kecil sehingga bank dinilai masih memiliki kemampuan dalam mengatasi risiko pembiayaan yang bermasalah yang muncul akibat dari bentuk kegiatan pembiayaan bank itu sendiri.

Hasil penelitian ini mendukung penelitian yang dilakukan oleh Masruroh (2018) yang menunjukkan bahwa NPF nilai Sig. sebesar 0,535 > 0,05 yang artinya NPF tidak berpengaruh siginifkan terhadap Likuiditas (FDR). Hasil berbeda didapati oleh penelitian yang dilakukan oleh Muttaqin (2018) yang menunjukkan bahwa NPF nilai Sig. sebesar $0,0082<$ 0,05 yang artinya NPF berpengaruh signifikan terhadap Likuiditas (FDR).

\section{Pengaruh DPK, CAR dan NPF terhadap Likuiditas}

Hipotesis keempat yang diajukan dalam penelitian ini yaitu variabel DPK, CAR, dan NPF secara bersama-sama atau simultan memiliki pengaruh terhadap Likuiditas (FDR). Hal ini bisa dilihat dari perolehan nilai sig. sebesar 0,000 < 0,05 , sehingga DPK, CAR, dan NPF secara simultan berpengaruh positif dan signifikan terhadap likuiditas (FDR). Dengan demikian $\mathrm{H}_{4}$ dapat diterima.

DPK, CAR, dan NPF merupakan faktor-faktor yang dapat mempengaruhi kinerja suatu bank. Faktor-faktor ini dapat digunakan untuk mengukur ataupun menilai kesehatan suatu bank. Hasil penelitian menunjukkan ada pengaruh signifikan antara variabel DPK, CAR, dan NPF terhadap Likuiditas (FDR) yang artinya peningkatan yang terjadi pada DPK, CAR, dan NPF dapat mengakibatkan meningkatnya Likuiditas (FDR) suatu bank.

\section{IV.KESIMPULAN DAN SARAN}

\section{A. Kesimpulan}

Berdasarkan hasil analisis data dan pembahasan hasil penelitian, maka dapat diambil kesimpulan sebagai berikut:

1. Terdapat pengaruh yang positif dan signifikan antara DPK terhadap Likuidtas (FDR) pada Perbankan Syariah tahun 20152019.

2. Terdapat pengaruh yang positif dan signifikan antara CAR terhadap Likuidtas (FDR) pada Perbankan Syariah tahun 20152019.

3. Tidak Terdapat pengaruh yang signifikan antara NPF terhadap Likuidtas (FDR) pada Perbankan Syariah tahun 2015-2019.

4. Terdapat pengaruh yang positif dan signifikan antara DPK, CAR, dan NPF terhadap Likuidtas (FDR) pada Perbankan Syariah tahun 2015-2019.

\section{B. Saran}

Berdasarkan kesimpulan dari analisis data dan pembahasan hasil penelitian yang telah disajikan, maka peneliti memberikan saran yang diharapkan memberi manfaat kepada pihak terkait. Adapun saran yang dapat disampaikan, yaitu sebagai berikut:

1. Hasil penelitian DPK berpengaruh terhadap likuiditas. Untuk itu maka disarankan pihak manajemen bank untuk mempertahankan kepercayaan masyarakat untuk menghimpun dananya ke bank syariah. Sehingga DPK dapat meningkat dan likuiditas bank dapat terjaga dengan baik.

2. Hasil penelitian CAR berpengaruh terhadap likuiditas. Untuk itu disarankan bagi pihak manajemen bank dapat menjaga dan mempertahankan risiko permodalan akibat dari kegiatan operasionalnya. Sehingga likuiditas bank tetap terjaga.

3. Hasil penelitian NPF tidak berpengaruh terhadap likuiditas. Untuk itu disarankan bagi pihak manajemen bank untuk mengatasi risiko kredit atas pembiayaan yang bermasalah dan mempertahankan rasio NPF sesuai dengan yang disarankan Bank Indonesia.

\section{DAFTAR PUSTAKA}

Antonio, M. S. (2016). Bank Syariah Dari Teori Ke Praktek (Cetakan Keduapuluh Enam). Jakarta: Gema Insani.

Bank Indonesia (2004). Surat Edaran Bank indonesia NO 6/23/dpnp 20014 Sistem Penilaian Tingkat Kesehatan Bank Umum dan Lampiran. Dipetik Oktober 20, 2020, dari Bank Indonesia: https://www.bi.go.id/id/archive/arsip-peraturan/Pages/ketentuan\%20perbankan.aspx

Dendawijaya, L. (2009). Manajemen Perbankan, Edisi Kedua. Jakarta: Ghalia Indonesia.

Ikatan Bankir Indonesia. (2014). Memahami Bank Syariah. Jakarta: PT Gramedia Pustaka Utama. 
Website : http://ekomaks.unmermadiun.ac.id/index.php/ekomaks

Kasmir. (2014). Dasar-dasar Perbankan (Edisi Revisi). Depok: PT Raja Grafindo Persada.

Kasmir. (2019). Analisis Laporan Keuangan. Jakarta: PT Raja Grafindo Persada.

Masruroh, M. (2018). Analisis Faktor-faktor yang Mempengaruhi Likuiditas Perbankan Syariah di Indonesia (2011-2016). Skripsi. Dipetik September 1, 2020, dari https://dspace.uii.ac.id/handle/123456789/7722

Muttaqin, M. (2018). Analisis Faktor-faktor Yang Mempengaruhi Likuiditas Perbankan Syariah Pada Periode 2013-2017. Skripsi. Dipetik Oktober 23, 2020, dari http://e-repository.perpus.iainsalatiga.ac.id/4786/1/skripsi\%20taqin.pdf

Nuraini. (2011, 9 26). Perbankan Syariah Tahan Banting Hadapi Krisi Global. Dipetik 10 25, 2020, dari Republika: https://www.republika.co.id/berita/ekonomi/keuangan/11/09/26/ls3sl0-perbankan-syariah-tahan-banting-hadapi-krisis-global

Suhartono, D. A., Zahroh, Z. Z., \& Azizah, D. F. (2017). Analisis Tingkat Kesehatan Bank Dengan Menggunakan Metode Risk Based Bank Rating (Studi Pada Bank Milik Pemerintah Pusat Yang Terdaftar Di Bursa Efek Indonesia Tahun 2012-2015). Jurnal Administrasi Bisnis, 46(1). Dipetik 10 17, 2020, dari http://administrasibisnis.studentjournal.ub.ac.id/index.php/jab/article/view/1791

Susilowati, E. (2016). Pengaruh Dana Pihak Ketiga (DPK), Capital Adequacy Ratio (CAR), dan Non Performing Financing (NPF) Terhadap Likuiditas Perbankan Syariah di Indonesia Periode 2011-2015. Skripsi. Dipetik September 15, 2020, dari http://repository.uinjkt.ac.id/dspace/handle/123456789/33259

Utami, M. S., \& Muslikhati, M. (2019). Pengaruh Dana Pihak Ketiga (DPK), Capital Adequacy Ratio (CAR), Non Performing Financing (NPF) Terhadap Likuiditas Bank Umum Syariah (BUS) Periode 2015-2017. Falah: Jurnal Ekonomi Syariah, 4(1), 33-43. Dipetik September 15, 2020, dari http://202.52.52.22/index.php/JES/article/view/8495. 